УДК 123.1: 123.2: 115

DOI 10.35423/2078-8142.2020.2.2.03

Ruslan Myronenko,

PhD Student, department of logic, Taras Shevchenko National University of Kyiv, Kyiv, Ukraine e-mail:mironrus@gmail.com ORCID: https://orcid.org/0000-0003-4058-9772

\title{
RECONSTRUCTION OF THE STAGIRITE ARGUMENT AGAINST THE FATALISM OF FUTURE EVENTS
}

The question of free will and determinism is one of the most discussed in analytic philosophy. This is because interdisciplinary research has entered the field of studying the brain and consciousness and often, consciousness is presented as an invention, an epiphenomenon. One of the attributes of consciousness is free will. The prehistory of modern research in the field of free will is the discussion about the need for future events, which was first analyzed by Stagirite in chapter 9, "On Interpretation". Despite all the analyticity and consistency of Aristotle's works, this work is full of gaps in argumentation and formulations ambiguity. In this regard, over two thousand years, philosophers have described many reconstructions in this chapter's argumentation and interpretations. Conventionally, the question of fatalism can be divided into two intersecting directions: logical fatalism and theological fatalism. This article examines the first direction and will relate to the understanding of fatalism and arguments against it in the context of the development of logic and theory of argumentation in the 20th century. The first logician who radically revised the foundations of logic to build an argument against future events' fatalism was Jan Lukasiewicz. We can say that all his life Lukasiewicz fought against determinism and tried to find a logical basis for human freedom of will. However, the main discussion on this issue took place in the middle of the 20th century between the logicians whose work will be considered in this article: Linsky Leonard, Butler Ronald, Storrs McCall, and others. The discussion was conducted around understanding such philosophical concepts

(C) Myronenko Ruslan, 2020 
and their ontological status: time, truth, a necessity. Also, in the wake of Lukasiewicz, they clarified such logical concepts as bivalence and the law of the excluded third. Of particular interest was the emergence of logical modalities, true/false, which can change their meaning over time, which led to the emergence of new informal logic.

Keywords: free will, fatalism, Aristotle, Stagirite, Interpretation, Formal logic, Informal logic, bivalence.

Almost 2,500 years ago, in the Saronic Gulf of the Aegean Sea near Athens, a naval battle of the united Greek fleet against the Persian kingdom took place. The Persian fleet was defeated. In anticipation of this battle, a difficult question is posed: will there be a battle tomorrow or not? After all, we can say with confidence whether the battle will take place tomorrow or not. But what about the truth of this statement? Moreover, does it not follow from the truth of this statement that this event is necessary? Stagirite first considered these and other questions from a logical point of view in the 9th chapter, "Interpretation".

The brevity of the narrative, the ambiguity of the context, and the lack of explanations do not contribute to understanding and lead many researchers in this field to different reconstructions of this text.

Let's clarify the basic concepts that are used by logicians to interpret this text of Aristotle. The fatalistic argument is an argument that is first presented in chapter 9 of "Interpretation." and consists of deriving future events from logical laws. The causality principle is one of the most general physical principles that sets the permissible limits for each other's influence of events [5]. The principle of bivalence, in short, means that every statement is true or false.

Note that the fatalistic argument presented here does not imply the principle of causality but relies entirely on logic. It is from the complete application of the principle of logical bivalence that it is deduced that all events are predetermined and people's actions. The mutual conditionality of statements with the state of affairs described by these statements is established, and this condition is logical, not causal. The question is how, taking the principle of bivalence as a starting point, Aristotle, in the cited text, comes to such far-reaching conclusions about the necessity of everything that happens, that is, substantiates the thesis 
that the complete application of the logical principle of bivalence entails fatalism, later called logical fatalism.

Several researchers indicate that this thesis was generally accepted in antiquity, at least in most Hellenistic schools [9, p. 278].

The modern discussion was laid by the famous Polish logician J. Lukasiewicz, who introduced a third truth value, different from "truth" and "false," for future random events. And then, the question immediately arose about the status of classical logic itself. R. Taylor, J. Hintikka, D. Williams, W. Quine, G. von Wright, A. Pryor, L. Linsky, J. Ryle and others joined the discussion at its first stage. The focus was on the following fundamental issues: the reality of the future, the relationship of truth to time, the relationship between truth and events, the doctrine of divine omniscience, the logical structure of a forecast, types of necessity, etc. Moreover, of course, the question of the logic of statements about future random events was raised. Simultaneously, the solution of these issues mainly depended on which of the concepts of time - dynamic or static - was adopted by this or that philosopher.

Before considering the discussion to identify the range of issues and problems caused by the Aristotelian text, let us dwell on the initial logical principles (laws) that underlie the problem of future randomness posed by Aristotle.

Recall that the principle of logical bivalence states that every statement is true or false. In turn, the principle of the excluded third states that of two conflicting statements, one must be true. Formally, it looks like this:

(1) $T(p) V * F(p)$,

(2) $T(p) V * T(\sim p)$,

where $\mathrm{p}$ is a propositional variable; $\sim \mathrm{p}-$ a statement that contradicts $\mathrm{p}$ and reads as not-p; T (p) and F (p) denote, respectively, "true that $\mathrm{p}$ " "false that $\mathrm{p} " ; \mathrm{V} *$ denotes strict disjunction and reads either-or, but not both.

Principle (2) will be called the semantic formulation of the law of the excluded middle, which is written in the following form:

(3) $\mathrm{p} V \sim \mathrm{p}$. 
Formula (3) coincides with (2) if A. Tarski's scheme takes place, which asserts that the phrase "it is true that ..." preceding the statement "p" is redundant in classical logic, that is,

\section{$T(p) \equiv p$,}

where $\equiv$ reads "identically".

It is easy to see that if (3) is a theorem of some logical system and $T(p) \equiv p$ holds for this system, and also the usual definition of falsity is taken: "falsity is the truth of the negation of a (contradictory) statement" [2, p. 541], i.e., $F(p) \equiv T(\sim p)$, then $\mathrm{T}(\mathrm{p}) \mathrm{V}^{*} \mathrm{~F}(\mathrm{p})$ also takes place in this system. In this sense, the bivalence principle (1) and the law of the excluded third (3) are equivalent. Those. Applying Tarski's scheme to (p V p ), we obtain $T(p) V * T(\sim p)$, then using the definition for $\mathrm{F}(\mathrm{p})$, we have $\mathrm{T}(\mathrm{p}) \mathrm{V} * \mathrm{~F}(\mathrm{p})$. As $\mathrm{G}$. von Wright writes, the adoption of Tarski's scheme leads to the fact that "any attempt to draw a strict distinction between the Law of the Excluded Third and the Law of Bivalence is in vain" [2, p. 544].

Continuing von Wright's thought, this is possible if the truth concept is not timeless, as is the case with statements about future random events. For Aristotle, the real subtlety lies in the fact that from his timeless definition of the concepts "truth" and "false," it follows that the law of the excluded middle coincides with the principle of bivalence. It is with this that Aristotle begins the seventh chapter of the fourth book of Metaphysics: "In the same way, there can be nothing intermediate between the two members of the contradiction, and concerning one thing, it is necessary to either affirm or deny anything. This becomes clear if we first define what is true and false. Namely: to speak of a being that it does not exist, or of a carrier that it is, is to speak falsely; and to say that the being is and the non-being is not is to say the true" [1].

Martha Neale drew attention to this [10, p. 46-47], for the first time making the above transition from (3) to (1), as a result of which she rejected the solution A Stagirite of the problem of future randomness, which consists in distinguishing between these two principles, based on which (1) is discarded, but (3) is accepted. Indeed, if (1) and (3) are equivalent, then the negation of one principle entails the other's negation. 
Confusing the principle of bivalence with the law of the excluded middle, and often merely identifying them, is a prevalent mistake. The transition from (2) to (1), or vice versa, is based on the formula $F(p) \equiv T(\sim p)$, which in many works is taken as a definition of falsity or only as an axiom. This formula assumes both the principle of twovagueness (1) and the excluded third's semantic principle (2). Thus, in the proof of (1) from (3), a logical error "vicious circle" was made, since principle (1) is proved with the help of itself.

So, from the principle of classical logic $\sqrt[F(p) \equiv T(\sim p)]{ }$, it follows that it is two-valued and the semantic principle of the excluded third takes place in it, and, consequently, (3) based on the Tarski scheme. However, this does not mean that these principles are equivalent.

There are various logical systems where the principle of bivalence is violated in an explicit form, but the excluded middle law takes place. The difference between these principles is more resonant, even more, fundamental than it can be expressed at the formal level. Note that the principle of bivalence applies only to statements and therefore is only a logical principle, the principle of the theory of truth, while the content of the law of the excluded third is by no means exhausted by the form $\mathrm{p} \mathrm{V} \sim \mathrm{p}$, since, in addition to its logical status, it also has a metalogical and ontological status.

In the 20th century, a strict distinction between the bivalence principle (1) and the excluded third (2) was first drawn by the famous Polish logician Jan Lukasiewicz. This resulted from his refutation of the Aristotelian fatalistic argument, as a result of which Lukasiewicz concluded that statements about future accidents are not true and not false [3, p. 125].

The timeless understanding of the truth underlying classical logic is the starting point in an article by the American professor D. Williams [11], which is already directly devoted to tomorrow's naval battle. The first question that starts and ends this article is: is the future real? Here Williams entirely agrees with B. Russell: "The past and the future must be recognized as real as the present, and a certain emancipation from the slavery of time is a critical philosophical thought" [8, p.171]. Moreover, time itself also has a spatial characteristic; all events, past, 
present, and future are already located on world lines and exist as part of the world whole. Williams' central thesis looks like this: "the past, present, and future are on the same ontological level with each other, and with the west and south, and are equally real" [11, p. 306]. Hence, it is clear why Williams criticizes the famous American philosopher Charles Broad, who resolutely denies the reality of the future and, in this connection, since there is no future, denies the validity of statements about the future. This means that for Broad, there is no problem with the truth of statements about future events.

The second question - the relation of truth to time - follows from the first solution, which allows Williams to assert: "the statement is true once, always true" [11, p. 283]. Here, Williams adopts Quine's "timeless" theory of the truth of statements, which erases any formal distinction between statements' timing.

The third question is the logic of statements about the future (random) events. Based on the accepted concepts of the future and truth, this logic is on the side of the classical, asserting that from the statement and its denial, one must be true, and the other false: "Consequently, either the statement "a sea battle will take place in the Aegean Sea in 24 hours (or a million years ) "Is true, or" the sea battle will not take place "is true" [11, p. 284]. At the same time, we note that Williams' principle of bivalence and the semantic principle of the excluded third do not differ and act as the law of the excluded third (3), which is always true (Williams does not consider the presence of Lukasiewicz's multivalued logics a serious argument). The truth of statements about future events is completely indifferent. to determinism. Therefore, William argues, the Stagirite is mistaken when it believes that the truth of the excluded middle law is compatible with the fact that none of the members of the disjunction is true. In other words, $\mathrm{T}(\mathrm{p} \mathrm{V} \sim \mathrm{p})$ is compatible with $\sim \mathrm{T}(\mathrm{p}) \& \sim \mathrm{T}(\sim \mathrm{p})$. This "compatibility" Williams calls "sheer contradiction" [11, p. 290].

The debate on the Aristotelian problem of future randomness was preceded by a debate that continues to this day, prompted by the work of the English philosopher J. McTaggart, who put forward the famous argument about the unreality of time, first published in 1908 [7]. The analytical philosophy of the twentieth century was faced with a difficult 
problem here, and almost every philosopher, in a latent or explicit form, tried to resolve the McTaggart paradox.

Discussion of the McTaggart paradox in modern literature gradually acquired the character of a dispute about the logical foundations of constructing two different concepts of time. Moreover, this should directly follow, for example, the solution of the problem of the logical status of statements about future (random) events, having received justification in terms of a particular concept of time.

Proponents of the dynamic concept of time (the so-called Atheory of time), claiming that the past and the future differ ontologically - past events were once present, and future events exist only in possibility - believe that this difference can be better clarified by the logical asymmetry between the past and the future, namely: all statements about the past are either true or false now. At the same time, some statements about the future are neither true nor false now. Proponents of the static concept of time (the so-called B-theory of time) cannot accept this logical asymmetry because they do not accept ontological differences between events at different times. All events included in history are equally real and defined and can be fully described by timeless true or false statements.

Thus, the discussion caused by the McTaggart paradox clarifies the discussion we are considering, and from this, so sharply different views on the status of logic itself become clear. While Williams and Quine are shocked to question the essential foundations of logic, another approach leaves them alone.

In an article by L. Linsky [6], in which he criticizes Williams' position and offers his own, a solution to Aristotle's problem is proposed, namely: the application of the law of the excluded third is limited only in a modularized form and therefore the compatibility $\mathrm{N}(\mathrm{pV} \sim \mathrm{p}) \mathrm{c}$ $\sim \mathrm{N}(\mathrm{p}) \mathrm{V}^{*} \sim \mathrm{N}(\sim \mathrm{p})$, is accepted, where $\mathrm{N}$ is read as "it is necessary that"... In support of his interpretation, Linsky refers to Stagerite and notes that such an interpretation does not lead to a contradiction.

A definite result of the initial period of discussion is the article [4]. Criticizing previous interpretations of Aristotle, Butler offers his own, for which he distinguishes three types of necessity [4, p. 268269]: 
1) Logical necessity, which is denoted as "L". Thus, some expressions' truth is logically necessary only under their form, regardless of the truth or falsity of their components. For example, the law of the excluded middle is logically necessary. $L(p \mathrm{~V} \sim \mathrm{p})$ for any statement $\mathrm{p}$ about the past, present, or future;

2) Irrevocable necessity of what has already happened. This kind of necessity refers to the past and present;

3) The causal necessity of what is predetermined, which is denoted as "S".

The last two types of necessity are similar in that if something happens or is predetermined, it cannot become different. What Stagirite denies is the $S(p) V^{*} S(\sim p)$ principle. It follows from this that the truth status of the statement "tomorrow there will be a sea battle" is not intermediate between truth and falsehood, as in Lukasiewicz, but not yet predetermined. However, in the morning, such a statement will already be irreversibly true or false. Thus, Butler's theory of truth, which he attributes to Aristotle, allows for changes in truth values over time and even a change in their modal status [4, p. 270].

We see that the Aristotelian text's possible interpretations "on interpretation" turned out to be very diverse. The problems of philosophy and logic connected with them also turned out to be multifactorial: various points of view on the truth status of statements about future random events are proposed, the status of logical principles is discussed, the need to develop theories of temporal statements is indicated, linguistic problems are posed regarding the structure of forecasts, the foundations of the theory of physical modalities are laid. All this takes place in the context of the relationship between truth, necessity, and time. Further discussion significantly deepens and expands the original problematics. A powerful incentive for this is the incessant attempts of more and more commentators and researchers to penetrate the secret of Aristotelian thought. Because, it would seem, behind a little question about the truth of statements about future random events, explicitly or implicitly, consciously or unconsciously, eternal questions arise again: what is time? What is the future? Is a person free? Therefore, it is not surprising that the discussion's tension will increase, and the number of works will increase. 


\section{REFERENCES}

Aristotle. (1976). Metaphysics: In 4 vols. Moscow: Misl', Vol. 1. 550 p. [In Russian].

Wright, G. H. (1986). Logical and philosophical studies. Selected Works. Moscow: Progress. 600 p. [In Russian].

Lukasiewicz, Jan. (2012). About the principle of contradiction in Aristotle. Moscow - St. Petersburg: TsGI. 256 p. [In Russian].

Butler Ronald, J. (Apr., 1955). Aristotle's Sea Fight and Three-valued Logic. In: The Philosophical Review, Vol. 64, No. 2, 264-274.

Green, Celia. (2003). The Lost Cause: Causation and the Mind-Body Problem. Oxford: Oxford Forum. 280 p.

Linsky, Leonard. (Apr., 1954). Professor Donald Williams on Aristotle. In: The Philosophical Review, Vol. 63, No. 2, 250-252.

Gale, Richard M. (Ed.). (1968). The Philosophy of Time: A Collection of Essays. Palgrave Macmillan UK. 514 p.

Russel, B. (1926). Our knowledge of the external world. London. 250 p.

Storrs, McCall. (Oct., 1966). Temporal Flux. In: American Philosophical Quarterly, Vol. 3, No. 4. 270-281 pp.

Kneale, William \& Kneale, Martha. (1985). In: Development of Logic. Oxford University Press, USA. 972 p.

Williams, D. (1951). The sea-fight tomorrow. Structure, Method and Meaning: Essays in Honor of Henry M. Sheffer. Liberal Arts Press. 306 p.

\section{ЛITЕРАТУРА}

1. Аристотель. Метафизика. Аристотель. Собр. соч. В 4 т. Москва : Мысль, 1976. Т. 1.550 с.

2. Вригт Г. Х., фон. Логико-философские исследования. Избранные труды. Москва : Прогресс, 1986. 600 с.

3. Лукасевич Ян. О принципе противоречия у Аристотеля. М. СПб. : ЦГИ, 2012. 256 с.

4. Butler Ronald J. Aristotle's Sea Fight and Three-valued Logic. The Philosophical Review. 1955. Vol. 64. No. 2. P. 264-274. 
5. Green Celia. The Lost Cause: Causation and the Mind-Body Problem. Oxford : Oxford Forum. 2003. 280 p.

6. Linsky Leonard. Professor Donald Williams on Aristotle. The Philosophical Review. 1954. Vol. 63. No. 2. P. 250-252.

7. The Philosophy of Time: A Collection of Essays / eds. Gale Richard M. Palgrave Macmillan UK, 1968. 514 p.

8. Russel B. Our knowledge of the external world. London, 1926. $250 \mathrm{p}$.

9. Storrs Mc Call. Temporal Flux. American Philosophical Quarterly. 1966. Vol. 3. No. 4. P. 270-281.

10. Kneale William, Kneale Martha. Development of Logic. Oxford University Press, USA, 1985. 972 p.

11. Williams D. The sea-fight tomorrow. Structure, Method and Meaning: Essays in Honor of Henry M. Sheffer. Liberal Arts Press, 1951. 306 p.

\section{Р. В. Мироненко}

аспірант Київського начіонального університету імені Тараса Шевченка; м. Київ, Україна; e-mail: mironrus@gmail.com; ORCID: https://orcid.org/ 0000-0003-4058-9772

\section{Реконструкція стагіритового аргументу проти фаталізму майбутніх nodiŭ}

\section{Анотація}

Питання про свободу волі і детермінізм - одне з найбільш обговорюваних в аналітичній філософії. Це пов'язано з тим, що міждисииплінарні дослідження вийшли у сферу вивчення мозку і свідомості, $i$ часто свідомість представлясться як вигадка, епіфеномен. Одним з атрибутів свідомості $\epsilon$ свобода волі. Передісторією сучасних досліджень щуодо свободи волі $\epsilon$ обговорення про необхідність майбутніх подій, яке вперше було проаналізовано ще Стагиритом у 9 главі «Про тлумачення». Не зважаючи на всю аналітичність і логічність праць Аристотеля, ия робота сповнена прогалин в аргументачії та неоднозначності формулювань. У зв'язку з иим, упродовж двох тисяч років філософи описали багато реконструкиій в аргументації та інтерпретацій иієї глави. Умовно питання про фаталізм можна розділити на два пересічних напрями: логічний фаталізм $i$ теологічний фаталізм. У даній статті розглянуто перший напрям; ана- 
$\overline{\text { лізується розуміння фаталізму і аргументів проти нього в розрізі розви- }}$ тку логіки і теорії аргументаиії у XX ст. Першим з логіків, хто кардинально переглянув основи логіки для побудови аргументації проти фаталізму майбутніх подій, був Ян Лукасевич. Можна сказати, щчо все життя Лукасевич боровся проти детермінізму і намагався знайти логічне підтрунтя для свободи волі людини. Але основна дискусія щодо иього відбувалася вже у середині $X X \mathrm{~cm}$. між логіками, прачі яких розглянуто у иій статті: Лінські Леонард, Батлер Рональд, Сторс МакКол та ін. Обговорення велося навколо розуміння таких філософських понять та їх онтологічного статусу, як час, істина, необхідність. Також услід за Лукасевичем уточнювали такі логічні поняття, як бівалентність $і$ закон виключеного третього. Особливий інтерес викликала поява логічних модальностей true/false, які можуть змінювати своє значення з часом, що сприяло появі нових неформальних логік.

Ключові слова: свобода волі, формальна логіка, неформальна логіка, Аристотель, бівалентність, Стагирит, інтерпретація, фаталізм. 